(C) 2020, The Authors. Published by Elsevier Inc. and Fass Inc. on behalf of the American Dairy Science Association ${ }^{\circledR}$. This is an open access article under the CC BY license (http://creativecommons.org/licenses/by/4.0/).

\title{
Effects of a Saccharomyces cerevisiae fermentation product on heat-stressed dairy cows
}

\author{
M. Al-Qaisi, ${ }^{1,2}$ E. A. Horst, ${ }^{1}$ E. J. Mayorga, ${ }^{1}$ B. M. Goetz, ${ }^{1}$ M. A. Abeyta, ${ }^{1}$ I. Yoon, ${ }^{3}$ L. L. Timms, ${ }^{1}$ \\ J. A. Appuhamy, ${ }^{1}$ and L. H. Baumgard ${ }^{1 *}$ \\ ${ }^{1}$ Department of Animal Science, lowa State University, Ames 50011 \\ ${ }^{2}$ Department of Animal Production, The University of Jordan, Amman, Jordan 11942 \\ ${ }^{3}$ Diamond V, Cedar Rapids, IA 52404
}

\begin{abstract}
The objective of this study was to evaluate the effects of supplementing a Saccharomyces cerevisiae fermentation product (SCFP) on body temperature indices, metabolism, acute phase protein response, and production variables during heat stress (HS). Twenty multiparous lactating Holstein cows (body weight $=675 \pm 12 \mathrm{~kg}$; days in milk $=144 \pm 5$; and parity $=2.3 \pm 0.1)$ were used in an experiment conducted in 2 replicates (10 cows/replicate). Cows were randomly assigned to 1 of 2 dietary treatments: control diet $(\mathrm{CON} ; \mathrm{n}=10)$ or the CON diet supplemented with $19 \mathrm{~g} / \mathrm{d}$ of SCFP (n $=10$; NutriTek, Diamond V, Cedar Rapids, IA). Cows were fed their respective diets for $21 \mathrm{~d}$ before initiation of the study. The experiment consisted of 2 periods: thermoneutral (period 1; P1) and heat stress (period 2; P2). During P1 (4 d), cows were fed ad libitum and housed in thermoneutral conditions for collecting baseline data. During P2 (7 d), HS was artificially induced using an electric heat blanket (EHB; Thermotex Therapy Systems Ltd., Calgary, AB, Canada). Cows were fitted with the EHB for the entirety of P2. Rectal temperature, respiration rate, and skin temperature were obtained twice daily (0600 and $1800 \mathrm{~h}$ ) during both periods. Overall, HS increased rectal temperature, skin temperature, and respiration rate $\left(1.4^{\circ} \mathrm{C}, 4.8^{\circ} \mathrm{C}\right.$, and 54 breaths/min, respectively) relative to $\mathrm{P} 1$, but no dietary treatment differences were detected. Compared with P1, HS decreased dry matter intake and milk yield (36 and 26\%, respectively), and the reductions were similar between dietary treatments. Relative to P1, HS increased milk fat content and milk urea nitrogen (17 and $30 \%$, respectively) and decreased milk protein and lactose contents (7 and 1.4\%, respectively). Overall, HS increased (52\%) plasma cortisol concentrations of CON, but circulating cortisol did not change in SCFP-
\end{abstract}

Received April 15, 2020

Accepted May 26, 2020.

*Corresponding author: baumgard@iastate.edu fed cows. Heat stress increased circulating lipopolysaccharide binding protein and serum amyloid A (SAA; 2- and 4-fold, respectively), and SCFP supplementation tended to decrease peak SAA $(\sim 33 \%)$ relative to CON cows. Overall, although HS did not influence circulating white blood cells and neutrophils, SCFP increased circulating white blood cells and neutrophils by 9 and $26 \%$, respectively, over CON in P2. In conclusion, HS initiated an acute phase protein response and feeding SCFP blunted the cortisol and SAA concentrations and altered some key leukocyte dynamics during HS.

Key words: electric heat blanket, Saccharomyces cerevisiae fermentation product, immune activation

\section{INTRODUCTION}

Heat stress (HS) jeopardizes animal welfare and compromises productivity (Armstrong, 1994; Kadzere et al., 2002). Despite implementing advanced management strategies (e.g., cooling systems, barn construction), HS remains a major constraint to the global dairy industry. Heat stress is an economic burden to all animal agriculture, and it costs $>\$ 1.5$ billion annually in the US dairy industry alone (Key and Sneeringer, 2014). Losses are explained by reduced milk yield, impaired growth rates, decreased reproduction, and compromised health (Armstrong, 1994). Many of the negative effects of HS on productivity result from compromised intestinal barrier integrity (Baumgard and Rhoads, 2013). Heat-stressed animals redistribute blood to the periphery to increase radiant heat loss, and, consequently, the gastrointestinal tract vasoconstricts to maintain blood pressure. Reduced blood flow to the splanchnic tissues causes hypoxia, enterocyte damage, and impaired epithelial barrier function, a scenario that allows LPS and undoubtedly many different types of antigens to infiltrate into circulation and subsequently cause immunoactivation and inflammation (Lambert, 2009; Sanz Fernandez et al., 2014; Koch et al., 2019).

Although sometimes inconsistent, most reports indicate that supplementing Saccharomyces cerevisiae 
fermentation product (SCFP) positively affects rumen $\mathrm{pH}$, DMI, milk yield, fermentation patterns, and immune function (Erasmus et al., 2005; Poppy et al., 2012; Zaworski et al., 2014; Yuan et al., 2015). Additionally, previous studies demonstrated that feeding SCFP has beneficial effects on key metrics of dairy cow production during HS (Bruno et al., 2009; Zhu et al., 2016). Hence, we hypothesized that supplementing an SCFP would alleviate or at least partially ameliorate the negative consequences of HS on key immune and stress indicators in dairy cows. Therefore, study objectives were to evaluate effects of an SCFP on body temperature indices, metabolism, and the acute phase protein response (APPR) in heat-stressed lactating dairy cows.

\section{MATERIALS AND METHODS}

\section{Animals and Experimental Design}

All procedures were approved by the Iowa State University Institutional Animal Care and Use Committee. Twenty multiparous lactating Holstein cows $(675$ $\pm 12 \mathrm{~kg}$ of BW; $144 \pm 5 \mathrm{DIM}$; parity $2.3 \pm 0.1$ ) were used in an experiment conducted in 2 replicates (10 cows/replicate). Cows were randomly assigned to 1 of 2 dietary treatments: control $\operatorname{diet}(\mathbf{C O N} ; \mathrm{n}=10)$ or the CON diet supplemented (during the mixing process in TMR) with $19 \mathrm{~g} / \mathrm{d}$ of SCFP ( $\mathrm{n}=10$; NutriTek, Diamond V, Cedar Rapids, IA). Pen-housed cows were fed their respective diets for $21 \mathrm{~d}$ before study initiation, during which individual animal feed intake was not measured. Following the initial feeding phase, cows were housed in individual box stalls $(4.57 \times 4.57 \mathrm{~m})$ for $14 \mathrm{~d}$ at the Iowa State University Dairy Farm (Ames, IA). Cows were acclimated for $3 \mathrm{~d}$ and implanted with jugular catheters as previously described (Baumgard et al., 2011). The experiment consisted of 2 periods. During period $1(\mathbf{P 1} ; 4 \mathrm{~d})$, cows were fed ad libitum and housed in thermoneutral (TN) conditions for collection of baseline body temperature indices and production variables. During period 2 (P2; 7 d), HS was artificially induced via an electric heat blanket (EHB) fitted to the cows. The EHB consisted of 12 infrared heating pads as a heat source (Thermotex Therapy Systems Ltd., Calgary, AB, Canada). The blanket was powered by a $110-\mathrm{V}$ electrical cord that connected to the EHB at the withers as previously described (Al-Qaisi et al., 2019, 2020). Environmental conditions throughout P1 and $\mathrm{P} 2$ were $19.1 \pm 0.3^{\circ} \mathrm{C}, 64.6 \pm 0.6 \%$ relative humidity, and 64.8 temperature-humidity index. Temperature and humidity were monitored and recorded every 10 min by a data logger (EL-USB-2-LCD, Lascar, Erie, $\mathrm{PA})$ and then condensed into daily averages.
All cows were fed a TMR (consisting primarily of corn silage and ground corn) once daily $(0800 \mathrm{~h})$ and orts were recorded. The TMR was formulated to meet or exceed the predicted requirements of energy, protein, minerals, and vitamins (NRC, 2001; Table 1). Throughout the experiment, cows were milked twice daily (0600 and $1800 \mathrm{~h}$ ) and yield was recorded. Milk samples from each cow were obtained daily (a.m. milking) during both experimental periods. Samples were stored at $4^{\circ} \mathrm{C}$ with a preservative (bronopol tablet; D\&F Control Systems, San Ramon, CA) until analysis by Dairy Lab Services (Dubuque, IA) using infrared analysis equipment and procedures approved by AOAC International (1995). In addition, milk samples (a.m. milking) were collected on d 4 of P1 and d 7 of P2 for milk fatty acid profile analysis. Total lipids were extracted according to previously described methods (Hara and Radin, 1978). Fatty acid methyl esters were trans-esterified with sodium methoxide as described by Chouinard et al. (1999). Gas chromatography (model 3800; Varian Analytical Instruments, Walnut Creek, CA) was used for fatty acids analysis. Briefly, $1 \mu \mathrm{L}$ of fatty acid methyl esters was injected into the gas chromatography with split ratio 99. Fatty acid methyl esters standards (GLC461; Nu-Chek Prep Inc., Elysian, $\mathrm{MN}$ ) were used to determine peak identification and quantification. The carrier gas was helium. Injector and detector temperatures were $220^{\circ} \mathrm{C}$ and helium flow rate was $1.1 \mathrm{~mL} / \mathrm{min}$.

During both P1 and P2, rectal temperature (Tr), skin temperature $(\mathbf{T s})$, respiration rate $(\mathbf{R R})$, and heart rate $(\mathbf{H R})$ were obtained twice daily (0600 and 1800 h). Rectal temperature was measured using a digital thermometer (GLA M700 digital thermometer, GLA Agricultural Electronics, San Luis Obispo, CA). Skin temperature was measured on the neck (not covered by the EHB) using an infrared thermometer (IRT207 Heat Seeker 8:1 mid-range infrared thermometer, General Tools, New York, NY). Respiration rate was determined by counting flank movements during 15 -s intervals and multiplied by 4 to obtain breaths per minute. Heart rate was determined using a stethoscope placed over the left side of the rib cage behind the elbow and heart beats were counted for a 15-s interval; this measurement was multiplied by 4 to obtain beats per minute.

Blood samples were collected daily at $0600 \mathrm{~h}$ during both P1 and P2 from the catheter and divided equally between a tube containing $\mathrm{K}_{2}$ EDTA (BD, Franklin Lakes, NJ; for plasma collection) and an empty glass tube (for serum collection). Serum samples were allowed to clot at room temperature for $1 \mathrm{~h}$ before centrifugation. Plasma and serum were harvested following centrifugation at $1,500 \times g$ for $15 \mathrm{~min}$ at $4^{\circ} \mathrm{C}$ and were subsequently frozen at $-20^{\circ} \mathrm{C}$ until analysis. In addi- 
tion, samples for complete blood count analysis were collected on $\mathrm{d} 3$ and 4 of $\mathrm{P} 1$ and $\mathrm{d} 1,3,5$, and 7 of $\mathrm{P} 2$. A 3-mL blood sample was collected from the catheter into a tube containing an anticoagulant $\left(\mathrm{K}_{2} \mathrm{EDTA}\right.$; BD) and stored at $4^{\circ} \mathrm{C}$ for $\sim 12 \mathrm{~h}$ before being submitted to the Iowa State University's Department of Veterinary Pathology (Ames, IA) for analysis.

Plasma glucose, insulin, nonesterified fatty acids (NEFA), BHB, BUN, LPS-binding protein (LBP), serum amyloid A (SAA), and cortisol concentrations were determined using commercially available kits according to the manufacturers' instructions (glucose: Wako Chemicals USA, Richmond, VA; insulin: Mercodia AB, Uppsala, Sweden; NEFA: Wako Chemicals USA; BHB: Pointe Scientific Inc., Canton, MI; BUN: Teco Diagnostics, Anaheim, CA; LBP: HK 503, Hycult Biotechnology, Uden, the Netherlands; SAA: Tridelta Development Ltd., Kildare, Ireland; cortisol: Enzo Life Sciences, Farmingdale, NY). The inter- and intraassay coefficients of variation for glucose, insulin, NEFA, BHB, BUN, LBP, SAA, and cortisol were 4.1 and $2.9 \%$, 10.1 and $3.6 \%, 9.8$ and $4.0 \%, 1.4$ and $4.3 \%, 4.5$ and $3.3 \%, 6.2$ and $3.8 \%, 13.9$ and $3.5 \%$, and 8.4 and $5.3 \%$, respectively.

Table 1. Ingredients and composition of $\operatorname{diets}^{1}$ ( $\%$ of DM unless noted)

\begin{tabular}{|c|c|c|}
\hline \multirow[b]{2}{*}{ Item } & \multicolumn{2}{|c|}{ Diet $^{2}$} \\
\hline & $\mathrm{CON}$ & SCFP \\
\hline \multicolumn{3}{|l|}{ Ingredient } \\
\hline Corn silage & 24.1 & 24.1 \\
\hline Baleage & 19.8 & 19.8 \\
\hline Alfalfa hay & 4.0 & 4.0 \\
\hline Ground corn & 27.6 & 27.6 \\
\hline Mineral and protein mix & 7.2 & 7.2 \\
\hline Whole cottonseed & 6.0 & 6.0 \\
\hline Corn gluten feed & 3.5 & 3.5 \\
\hline Soybean meal & 3.5 & 3.5 \\
\hline Soy Plus ${ }^{3}$ & 2.6 & 2.6 \\
\hline Molasses & 1.7 & 1.7 \\
\hline \multicolumn{3}{|l|}{ Chemical analysis } \\
\hline Starch & 28.2 & 29.8 \\
\hline $\mathrm{CP}$ & 16.9 & 17.0 \\
\hline $\mathrm{NDF}$ & 27.6 & 25.9 \\
\hline $\mathrm{ADF}$ & 19.3 & 18.0 \\
\hline $\mathrm{NE}_{\mathrm{L}}(\mathrm{Mcal} / \mathrm{kg}$ of $\mathrm{DM})$ & 1.66 & 1.68 \\
\hline
\end{tabular}

${ }^{1}$ Values represent an average of ration nutrient summary reports collected throughout the study. Diet DM averaged $53.30 \%$ for the CON and $55.99 \%$ for the SCFP ration.

${ }^{2} \mathrm{CON}=$ control diet; SCFP $=$ control diet supplemented with Saccharomyces cerevisiae fermentation product (NutriTek, Diamond V, Cedar Rapids, IA). Average nutrient levels for both rations: 5.06\% fat, $0.91 \% \mathrm{Ca}, 0.39 \% \mathrm{P}, 0.36 \% \mathrm{Mg}, 0.21 \% \mathrm{~S}, 1.22 \% \mathrm{~K}, 0.42 \% \mathrm{Na}$, $0.63 \% \mathrm{Cl}, 78.58 \mathrm{mg} / \mathrm{kg} \mathrm{Zn}, 45.66 \mathrm{mg} / \mathrm{kg} \mathrm{Mn}, 3.54 \mathrm{mg} / \mathrm{kg} \mathrm{Fe}, 13.62$ $\mathrm{mg} / \mathrm{kg} \mathrm{Cu}, 0.76 \mathrm{mg} / \mathrm{kg} \mathrm{Co}, 0.16 \mathrm{mg} / \mathrm{kg} \mathrm{Se}, 0.76 \mathrm{mg} / \mathrm{kg} \mathrm{I}, 6,167.2 \mathrm{IU} /$ $\mathrm{kg}$ vitamin A, 1,233.45 IU $/ \mathrm{kg}$ vitamin $\mathrm{D}$, and $24.66 \mathrm{IU} / \mathrm{kg}$ vitamin E. ${ }^{3}$ Mechanically processed soybean meal (Dairy Nutrition Plus, Ralston, IA).

\section{Statistical Analysis}

Each response variable (DMI, milk yield and composition, blood metabolites, inflammatory biomarkers, and complete blood count) in P2 was analyzed using repeated measures with an autoregressive covariance structure. The repeated effect was the day in P2. The average value of each response variable during $\mathrm{P} 1$ served as a covariate. Effects of treatment, day, their interaction, and the covariate were analyzed using PROC MIXED (SAS Institute Inc., Cary, NC). Those effects on milk SCC were analyzed using PROC GLIMMIX (SAS Institute Inc.) with Poisson distribution (ten Napel et al., 2009). To test the effects of period on the response variables, a separate analysis was carried out with a model including fixed effects of treatment, period, and their interaction and the random effect of cow using the MIXED procedure of SAS. Results are reported as least squares means and were considered different when $P \leq 0.05$ and a tendency if $0.05<P \leq$ 0.10 .

\section{RESULTS}

As expected, HS increased $\operatorname{Tr}\left(1.4^{\circ} \mathrm{C}\right), \mathrm{RR}(54$ breaths $/ \mathrm{min})$, and $\mathrm{Ts}\left(4.8^{\circ} \mathrm{C}\right)$ throughout $\mathrm{P} 2$ compared with P1 $(P<0.01$; Table 2$)$. There were no detectable differences in $\mathrm{Tr}, \mathrm{RR}$, and Ts $(P>0.23$; Table 2$)$ due to dietary treatment. Relative to P1, HR increased for all cows; however, the magnitude of increase (P1 vs. P2) was less for SCFP-fed cows compared with CON cows (treatment $\times$ period interaction; $P<0.01$; Table 2).

During P2, HS markedly decreased DMI (36\%; $P<$ 0.01; Table 3; Figure 1A) in both dietary treatments relative to $\mathrm{P} 1$, and the decrease was most prominent on d 4 of P2 $(\sim 46 \% ; P<0.01$; Figure 1A). Relative to P1, HS decreased milk production $(\sim 26 \% ; P<0.01$; Table 3 ; Figure 1B), and this reduction was most pronounced on d 5 of P2 $(33 \% ; P<0.01$; Figure $1 \mathrm{~B})$; however, no dietary treatment differences were observed $(P>0.60$; Figure 1B). Regardless of treatment, HS increased milk fat content and MUN (17 and 30\%, respectively; $P<$ 0.01 ; Table 3) relative to $\mathrm{P} 1$. In contrast, milk protein and lactose concentrations were moderately decreased (7 and $1.4 \%$, respectively; $P<0.01$; Table 3 ) relative to P1, and neither variable was influenced by dietary treatment. Milk SCC was not affected by HS but decreased in SCFP-fed cows relative to CON cows during P2 $(36 \% ; P<0.01 ;$ Figure 2).

Relative to P1, HS decreased the content of de novo $(\leq \mathrm{C} 14: 1)$ and mixed (C16:0 and 16:1) fatty acids (23.0 and 5.4\%, respectively; $P<0.01$; Supplemental Table 
Table 2. Effects of a Saccharomyces cerevisiae fermentation product on body temperature variables of lactating dairy cows ${ }^{1}$

\begin{tabular}{|c|c|c|c|c|c|c|c|c|}
\hline Item & \multicolumn{2}{|c|}{ Period $1^{2}$} & \multicolumn{2}{|c|}{ Period $2^{3}$} & SEM & \multicolumn{3}{|c|}{$P$-value } \\
\hline Rectal temperature $\left({ }^{\circ} \mathrm{C}\right)$ & 38.4 & 38.4 & 39.7 & 39.9 & 0.1 & 0.23 & $<0.01$ & 0.11 \\
\hline Respiration rate (breaths/min) & 34 & 36 & 87 & 91 & 2 & 0.31 & $<0.01$ & 0.53 \\
\hline Heart rate (beats/min) & $79^{\mathrm{c}}$ & $82^{\mathrm{bc}}$ & $87^{\mathrm{a}}$ & $85^{\mathrm{a}}$ & 2 & 0.83 & $<0.01$ & $<0.01$ \\
\hline
\end{tabular}

${ }^{\mathrm{a}-\mathrm{c}}$ Values within a row with different superscripts are statistically different $(P<0.05)$.

${ }^{1} \mathrm{CON}=$ control diet; SCFP $=$ control diet supplemented with Saccharomyces cerevisiae fermentation product (NutriTek, Diamond V, Cedar Rapids, IA).

${ }^{2}$ During period 1 , cows in both treatments were housed in thermoneutral conditions and allowed to eat ad libitum.

${ }^{3}$ During period 2, all cows were fitted with an electric heat blanket and allowed to eat ad libitum.

S1, https://doi.org/10.3168/jds.2020-18721), and the content of preformed fatty acids $(\geq \mathrm{C} 17: 0)$ increased (17\%; $P<0.01 ;$ Supplemental Table S1). Regardless of dietary treatments, HS decreased plasma glucose $(\sim 4 \% ; P<0.01 ;$ Table 4$)$, increased circulating NEFA, BHB, and BUN concentrations $(\sim 50, \sim 38$, and $\sim 18 \%$, respectively; $P<0.01$; Table 4 ), and did not affect circulating insulin $(P>0.25$; Table 4$)$ compared with P1. However, HS increased the insulin:DMI ratio $(77.5 \%$; $P<0.01$; Table 4) during P2 relative to $\mathrm{P} 1$, but this ratio was not influenced by dietary treatments. Heat stress increased cortisol concentrations $(52 \% ; P<0.05$; Figure 3) in CON, but circulating cortisol remained unaffected by HS in the SCFP-fed cows (Figure 3).

Overall, during P2, circulating LBP and SAA increased (2- and 4-fold, respectively) relative to $\mathrm{P} 1$ ( $P$ $<0.01$; Figure $4 \mathrm{~A}$ and B). Although no overall dietary treatment differences were observed, a post hoc analysis revealed a tendency for decreased circulating SAA on d 5 of P2 in SCFP-fed cows $(\sim 33 \% ; P=0.07$; Figure $4 \mathrm{~B})$ relative to $\mathrm{CON}$ cows. Overall and relative to $\mathrm{P} 1$, HS did not influence circulating white blood cells and neutrophils, but both were increased $(\sim 9$ and $\sim 26 \%$, respectively; $P \leq 0.05$; Figure $5 \mathrm{~A}$ and $\mathrm{B}$ ) in SCFP-fed cows compared with CON cows during P2. Regardless of dietary treatments, HS decreased circulating red blood cells, lymphocytes, basophils, hemoglobin, and hematocrit $(3,7,14,3$, and 4\%; $P<0.01$; Table 5). There was a treatment $\times$ period interaction on circulating platelets, as they remained unchanged in $\mathrm{CON}$ cows but increased in SCFP-fed cows during P2 (31\%; $P=$ 0.05 ; Table 5).

\section{DISCUSSION}

Many important production traits are adversely affected by HS, and thus this abiotic stressor is an enormous financial burden on the dairy industry (Key and Sneeringer, 2014). Several management strategies (e.g., cooling systems) have been implemented to ameliorate the negative consequences of HS, but hindered animal performance remains a problem during the warm summer months (Armstrong, 1994). Many of the deleterious effects of HS on productivity are likely mediated by reduced intestinal barrier integrity (Hall et al., 2001; Lambert et al., 2002; Baumgard and Rhoads, 2013). Impaired epithelial integrity allows for luminal contents (i.e., LPS and other toxins) to translocate into the portal and systemic circulation, and these antigens stimulate immune and inflammatory responses (Cronje,

Table 3. Effects of a Saccharomyces cerevisiae fermentation product on production variables of lactating dairy cows ${ }^{1}$

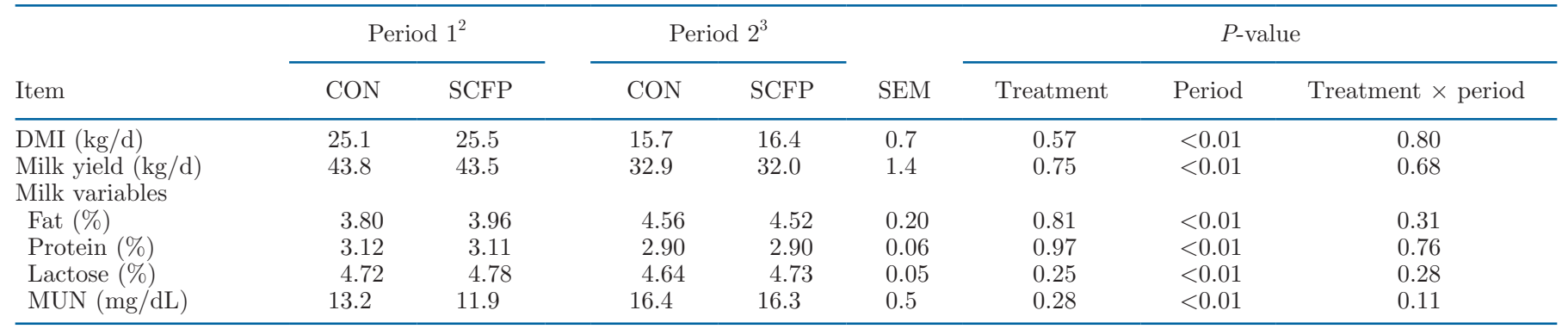

${ }^{1} \mathrm{CON}=$ control diet; $\mathrm{SCFP}=$ control diet supplemented with Saccharomyces cerevisiae fermentation product (NutriTek, Diamond V, Cedar Rapids, IA).

${ }^{2}$ During period 1 , cows in both treatments were housed in thermoneutral conditions and allowed to eat ad libitum.

${ }^{3}$ During period 2, all cows were fitted with an electric heat blanket and allowed to eat ad libitum. 

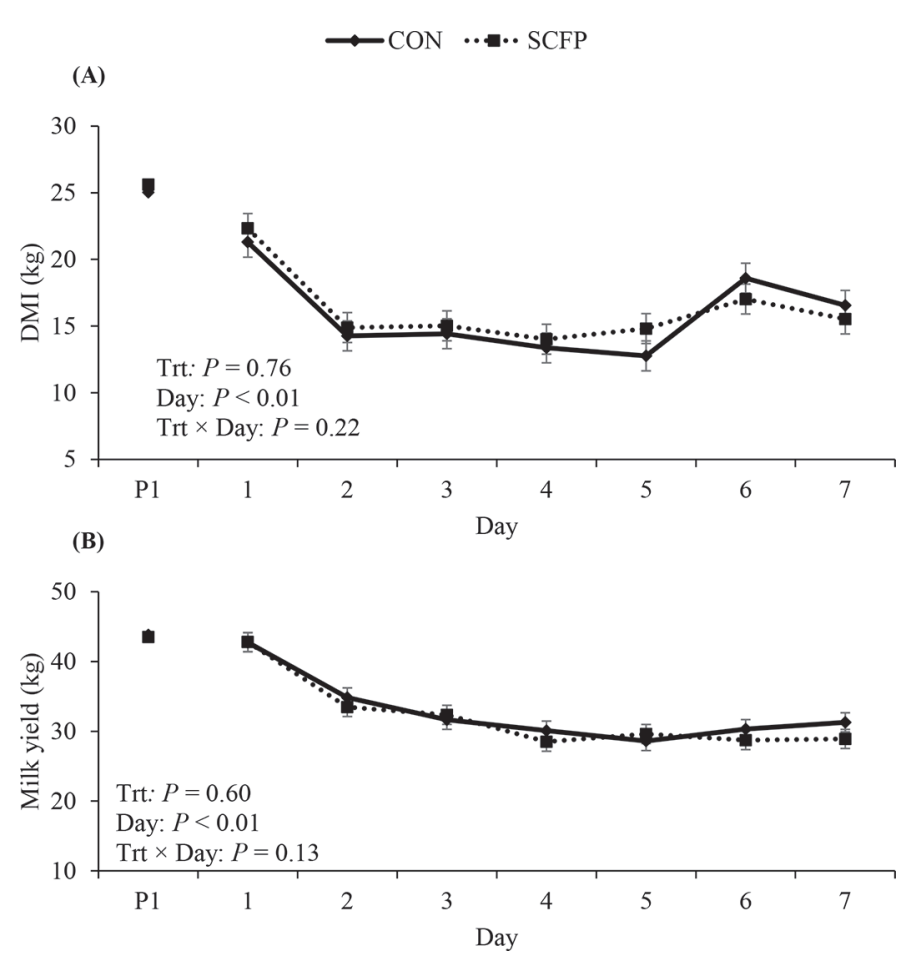

Figure 1. Effects of a Saccharomyces cerevisiae fermentation product (SCFP; NutriTek, Diamond V, Cedar Rapids, IA) on (A) DMI and (B) milk yield of heat-stressed lactating dairy cows. The treatment means of period 1 are represented by $\mathrm{P} 1$ on the $\mathrm{x}$-axis and were used as a covariate for period $2(\mathrm{P} 2)$. Results are expressed as LSM \pm SEM, and the $P$-values are from the statistical analysis of $\mathrm{P} 2$. $\mathrm{CON}=$ control; Trt $=$ treatment.

2005; Lambert, 2009; Baumgard and Rhoads, 2013). The immune system is energetically expensive, and when it is engaged it rearranges the hierarchy of nutrient partitioning away from milk synthesis (Kvidera et al., 2017). Therefore, dietary interventions that target intestinal toxin and pathogen binding, intestinal barrier function, or immune system modulation may improve productivity.

Feeding SCFP has improved DMI, milk yield, feed efficiency, and rumen pH (Erasmus et al., 2005; Poppy et al., 2012; Zaworski et al., 2014; Acharya et al., 2017). Additionally, previous studies have shown that feeding SCFP has beneficial effects on dairy cow performance during challenging situations such as HS (Schingoethe et al., 2004; Zhu et al., 2016), dietary aflatoxin challenge (Jiang et al., 2018), SARA (Li et al., 2016), and the transition period (Dann et al., 2000; Zaworski et al., 2014; Shi et al., 2019). In part, SCFP appears to affect productivity as an immunomodulator (Broadway et al., 2015; Shurson, 2018).

In the current study, HS was successfully induced via the EHB as demonstrated by marked increases in all body temperature variables evaluated (Table 2). This

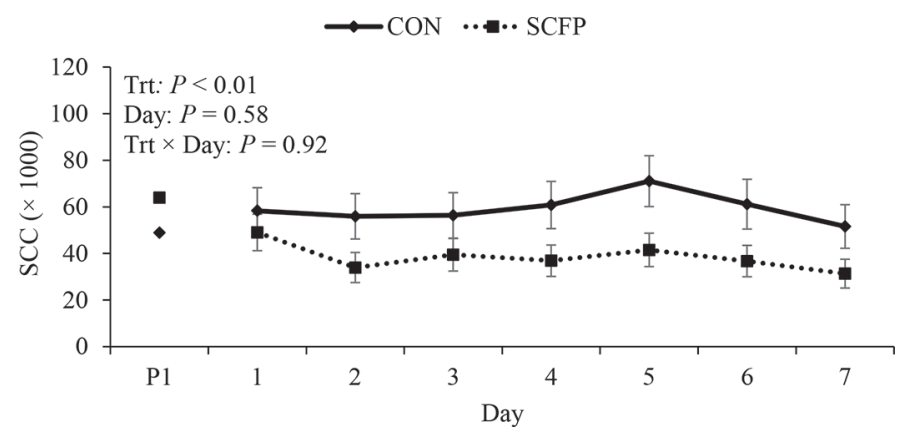

Figure 2. Effects of a Saccharomyces cerevisiae fermentation product (SCFP; NutriTek, Diamond V, Cedar Rapids, IA) on SCC of heatstressed lactating dairy cows. The treatment means of period 1 are represented by $\mathrm{P} 1$ on the $\mathrm{x}$-axis and were used as a covariate for period 2 (P2). Results are expressed as LSM $\pm \mathrm{SEM}$, and the $P$-values are from the statistical analysis of $\mathrm{P} 2 . \mathrm{CON}=$ control; $\mathrm{Trt}=$ treatment.

is consistent with our previous EHB studies (Al-Qaisi et al., 2019, 2020) and climate-controlled experiments (Rhoads et al., 2009; Shwartz et al., 2009; Wheelock et al., 2010; Baumgard et al., 2011). Although no dietary treatment differences were observed on $\mathrm{Tr}$, Ts, or RR during P2, the magnitude of HR increase (P1 vs. P2) was less severe in SCFP-supplemented cows compared with CON cows. Whether this response in HR is biologically meaningful is unclear. Regardless, the fact that there were no dietary treatment differences in most of the body temperature indices is not surprising because DMI and milk yield (2 key contributors to basal heat production) were similar between treatments.

In agreement with our previous EHB studies (AlQaisi et al., 2019, 2020) and climate-controlled experiments (Rhoads et al., 2009; Shwartz et al., 2009; Cowley et al., 2015), HS markedly decreased DMI (36\%) relative to P1. Decreased DMI represents a strategy to

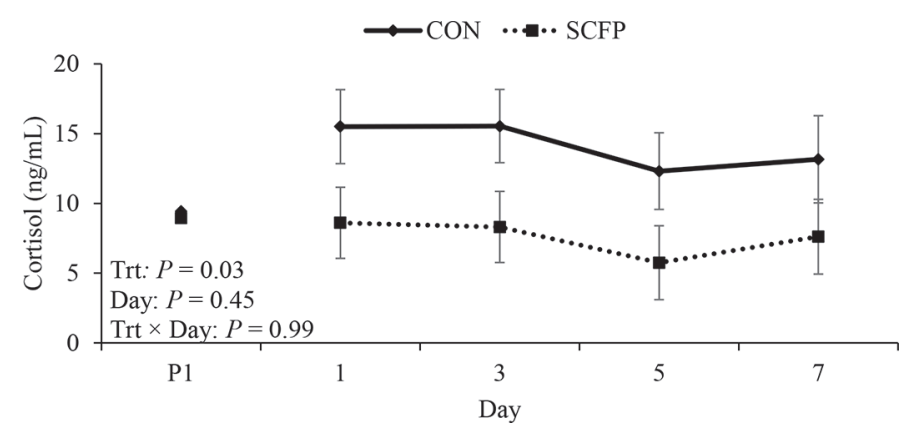

Figure 3. Effects of a Saccharomyces cerevisiae fermentation product (SCFP; NutriTek, Diamond V, Cedar Rapids, IA) on circulating cortisol of heat-stressed lactating dairy cows. The treatment means of period 1 are represented by $\mathrm{P} 1$ on the $\mathrm{x}$-axis and were used as a covariate for period $2(\mathrm{P} 2)$. Results are expressed as LSM \pm SEM, and the $P$-values are from the statistical analysis of $\mathrm{P} 2 . \mathrm{CON}=$ control; Trt $=$ treatment. 
Table 4. Effects of a Saccharomyces cerevisiae fermentation product on blood metabolites of lactating dairy cows ${ }^{1}$

\begin{tabular}{|c|c|c|c|c|c|c|c|c|}
\hline Item & \multicolumn{2}{|c|}{ Period $1^{2}$} & \multicolumn{2}{|c|}{ Period $2^{3}$} & SEM & \multicolumn{3}{|c|}{$P$-value } \\
\hline Glucose (mg/dL) & 72.0 & 73.1 & 68.9 & 70.7 & 1.7 & 0.50 & $<0.01$ & 0.74 \\
\hline Insulin:DMI & 0.019 & 0.021 & 0.035 & 0.036 & 0.003 & 0.73 & $<0.01$ & 0.81 \\
\hline $\mathrm{NEFA}^{4}(\mu \mathrm{Eq} / \mathrm{L})$ & 175.8 & 176.0 & 267.1 & 260.0 & 22.0 & 0.89 & $<0.01$ & 0.85 \\
\hline $\mathrm{BHB}(\mathrm{mg} / \mathrm{dL})$ & 5.8 & 6.3 & 8.3 & 8.4 & 0.5 & 0.61 & $<0.01$ & 0.51 \\
\hline
\end{tabular}

${ }^{1} \mathrm{CON}=$ control diet; SCFP $=$ control diet supplemented with Saccharomyces cerevisiae fermentation product (NutriTek, Diamond V, Cedar Rapids, IA).

${ }^{2}$ During period 1 , cows in both treatments were housed in thermoneutral conditions and allowed to eat ad libitum.

${ }^{3}$ During period 2, all cows were fitted with an electric heat blanket and allowed to eat ad libitum.

${ }^{4}$ Nonesterified fatty acids.

reduce metabolic heat production, and it is a conserved response across species during HS (Collin et al., 2001; Kadzere et al., 2002; Baumgard and Rhoads, 2013). A meta-analysis suggests that the effects of SCFP on DMI are dependent on stage of lactation (decreased during established lactation; Poppy et al., 2012), but DMI was similar between dietary treatments during HS, which agrees with previous SCFP reports (Schingoethe et al., 2004; Zhu et al., 2016). Understanding how stress influences the appetite-controlling effects of SCFP would provide utility to practical nutritional strategies.

Not unexpectedly, HS decreased milk yield (26\%) relative to P1, which corroborates our previous EHB studies (Al-Qaisi et al., 2019, 2020) and climate-controlled experiments (Rhoads et al., 2009; Shwartz et al., 2009; Cowley et al., 2015). However, no dietary treatment differences were observed on milk yield during HS, which agrees with Schingoethe et al. (2004). Other studies (Bruno et al., 2009; Zhu et al., 2016), however, reported positive effects of SCFP supplementation during HS on milk yield. Lack of dietary treatment differences in overall productivity (i.e., DMI and milk yield) in this study is not unanticipated as the experiment was powered for metabolic and immune activation markers and knowingly underpowered for production metrics. It would be of interest to evaluate SCFP's potential to improve economically important phenotypes during HS in the future.

Dietary treatment had no effect on milk fat percentage, which agrees with previous reports that evaluated SCFP during HS (Schingoethe et al., 2004; Zhu et al., 2016). However, HS increased milk fat content (17\%) relative to $\mathrm{P} 1$, which is consistent with previous results (Regan and Richardson, 1938; Rhoads et al., 2009; Baumgard et al., 2011; Al-Qaisi et al., 2020). This is interesting as normally milk fat content has a seasonal pattern and is typically the lowest during the warm summer months (Hays, 1926; Huber, 1996; Bouraoui et al., 2002). Reasons why discordant effects exist between natural HS and HS models are not clear, but most HS models are acute and intense (i.e., $<10 \mathrm{~d}$ ) and perhaps the low summer milk fat is part of the acclimation re-

Table 5. Effects of a Saccharomyces cerevisiae fermentation product on complete blood cell parameters of lactating dairy cows ${ }^{1}$

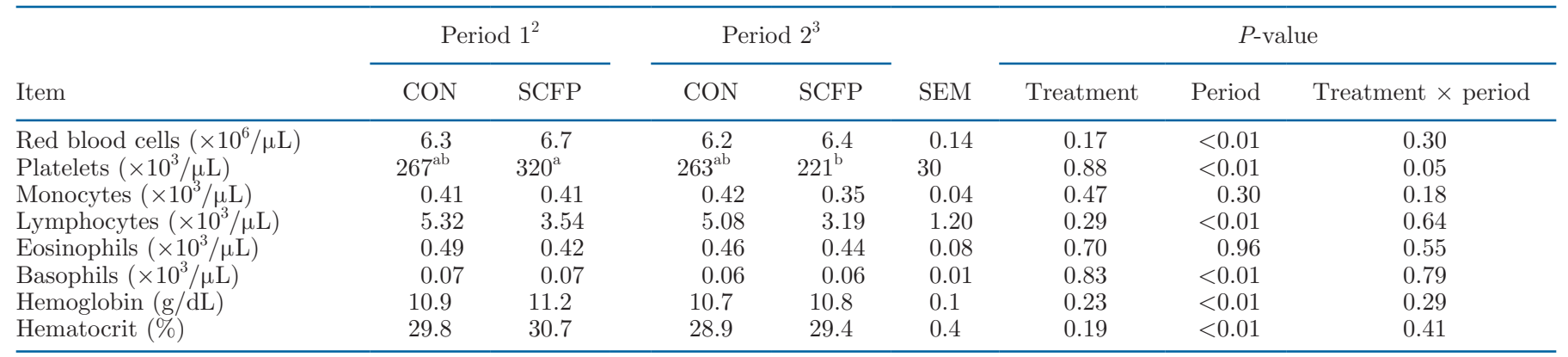

$\overline{\mathrm{a}, \mathrm{b}}$ Values within a row with different superscripts are statistically different $(P<0.05)$.

${ }^{1} \mathrm{CON}=$ control diet; SCFP $=$ control diet supplemented with Saccharomyces cerevisiae fermentation product (NutriTek, Diamond V, Cedar Rapids, IA).

${ }^{2}$ During period 1, cows in both treatments were housed in thermoneutral conditions and allowed to eat ad libitum.

${ }^{3}$ During period 2, all cows were fitted with an electric heat blanket and allowed to eat ad libitum. 
sponse (a physiological state that is not fully obtained in the climate chamber or EHB models). Regardless of dietary treatment, HS decreased the content of de novo derived fatty acids and increased the percentage of preformed fatty acids, and this altered profile during HS agrees with previous reports (Moody et al., 1971; Bandaranayaka and Holmes, 1976). Interestingly, the aforementioned changes in milk fatty acid origin (decreased and increased de novo and preformed, respectively) are normally associated with diet-induced milk fat depression (Bauman et al., 2008), not increased milk fat content as observed herein and in other HS models (Regan and Richardson, 1938; Rhoads et al., 2009). Clearly, a better understanding of how milk fat synthesis is regulated during HS is warranted.

Heat stress decreased milk protein content (7\%), which agrees with our previous HS results (Shwartz et al., 2009; Baumgard et al., 2011; Al-Qaisi et al., 2019), but it was unaffected by dietary treatment, which agrees with previous reports (Schingoethe et al., 2004; Zhu et al., 2016). Reduced milk protein composition is likely due to increased AA utilization for extramammary purposes (Gao et al., 2017) and potentially the direct ef-
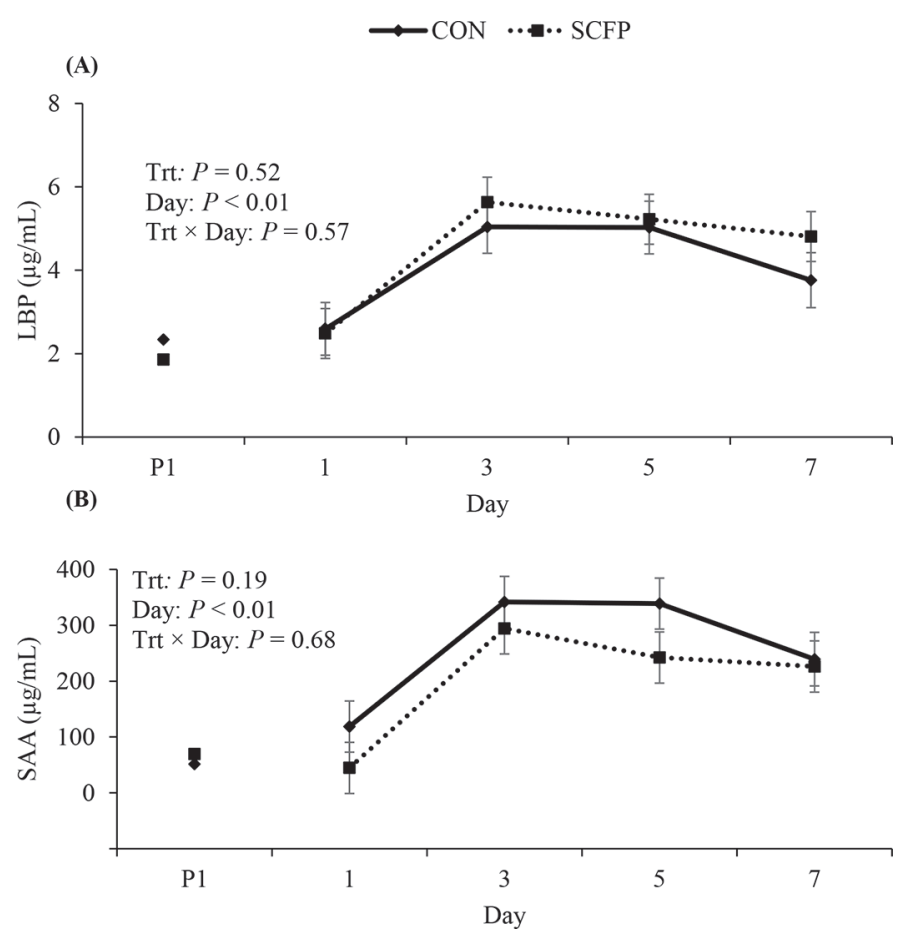

Figure 4. Effects of a Saccharomyces cerevisiae fermentation product (SCFP; NutriTek, Diamond V, Cedar Rapids, IA) on circulating (A) LPS-binding protein (LBP) and (B) serum amyloid A (SAA) of heat-stressed lactating dairy cows. The treatment means of period 1 are represented by $\mathrm{P} 1$ on the $\mathrm{x}$-axis and were used as a covariate for period (P2). Results are expressed as LSM \pm SEM, and the $P$-values are from the statistical analysis of $\mathrm{P} 2 . \mathrm{CON}=$ control; Trt $=$ treatment. fects of HS on mammary protein synthesis (Bernabucci et al., 2010; Cowley et al., 2015). The indirect effects of HS on milk protein synthesis may be mediated by either antigens (e.g., LPS) as mammary epithelial cells have the toll-like receptor-4 (Ibeagha-Awemu et al., 2008) or inflammation as this milk component is also markedly decreased in LPS infusion models (Hinz et al., 2012; Ning et al., 2018).

In agreement with previous HS studies (Rhoads et al., 2009; Shwartz et al., 2009; Wheelock et al., 2010; Al-Qaisi et al., 2020), HS decreased milk lactose content, but this effect was not rescued by SCFP, which corroborates previous results (Schingoethe et al., 2004; Zhu et al., 2016). The decreased milk lactose content could be attributed to an increase in extramammary glucose utilization during HS (discussed below) and reduced ruminal production of propionate and total VFA.

Heat stress increased MUN, and this corroborates with previous HS studies (Wheelock et al., 2010; Cowley et al., 2015; Gao et al., 2017; Al-Qaisi et al., 2019, 2020). Presumably, MUN increased because HS cows were mobilizing skeletal muscle to provide AA to produce acute phase proteins (Johnson, 2012) and glucose
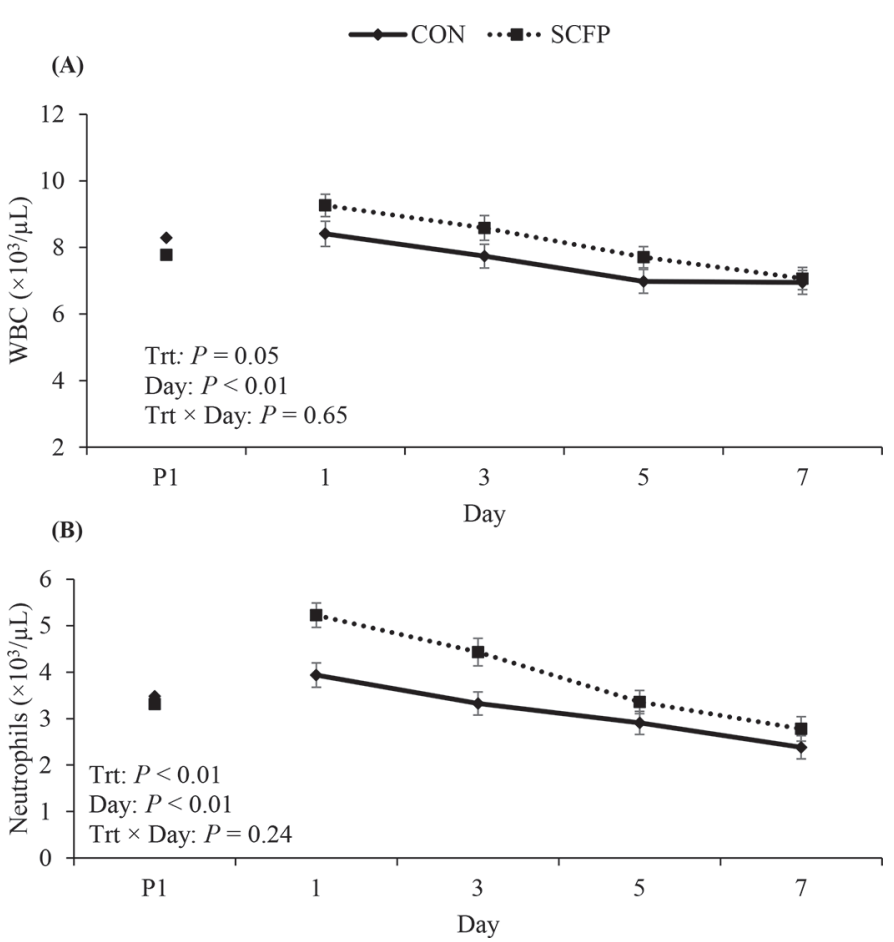

Figure 5. Effects of a Saccharomyces cerevisiae fermentation product (SCFP; NutriTek, Diamond V, Cedar Rapids, IA) on circulating (A) white blood cells (WBC) and (B) neutrophils of heat-stressed lactating dairy cows. The treatment means of period 1 are represented by $\mathrm{P} 1$ on the $\mathrm{x}$-axis and were used as a covariate for period 2 (P2). Results are expressed as LSM $\pm \mathrm{SEM}$, and the $P$-values are from the statistical analysis of $\mathrm{P} 2 . \mathrm{CON}=$ control; Trt $=$ treatment. 
(Baumgard and Rhoads, 2013). Feeding SCFP had no detectable effects on MUN, and this contradicts recent reports indicating that SCFP linearly decreased MUN during natural HS (Zhu et al., 2016) and during the transition period (Shi et al., 2019). The inconsistencies between studies might be due to different stages of lactation, HS severity, or different feed composition. Interestingly, SCC decreased (36\%) in SCFP-fed cows relative to $\mathrm{CON}$ cows during $\mathrm{HS}$, which is consistent with transition period studies (Bluel, 2006; Zaworski et al., 2014; Yuan et al., 2015). However, other studies (Dann et al., 2000; Ramsing et al., 2009) reported no effect of SCFP supplementation on milk SCC. Reasons for reduced SCC in SCFP-fed cows are not fully understood but likely involve the immunomodulatory effects of SCFP and the basal levels of immune activation (systemic and intramammary; as reviewed by Volman et al., 2008; Broadway et al., 2015). From a Streptococcus uberis challenge study, Vailati-Riboni et al. (2019) observed that SCFP-fed cows recovered faster from the challenge with greater milk yield with reduced SCC. Further investigating the effect of dietary SCFP on mammary health is of interest.

Dietary treatment did not affect circulating glucose; however, HS decreased glucose levels $(\sim 4 \%)$ relative to $\mathrm{P} 1$, which is similar to previous HS studies in cows (Itoh et al., 1998; Shwartz et al., 2009; Wheelock et al., 2010; Al-Qaisi et al., 2020), sheep (Achmadi et al., 1993), and pigs (Sanz Fernandez et al., 2014). Presumably, glucose concentrations are reduced because of decreased propionate delivery to the liver (i.e., decreased DMI) and increased glucose uptake by activated leukocytes (discussed below), which utilize copious amounts of glucose (Kvidera et al., 2017).

In the current study, no dietary treatment differences were observed in the insulin:DMI ratio or in circulating insulin, NEFA, BHB, or BUN during HS. However, despite the marked reduction in DMI during P2, HS increased the insulin:DMI ratio $(76 \%)$; this agrees with previous HS work in ruminants and pigs (O'Brien et al., 2010; Wheelock et al., 2010; Sanz Fernandez et al., 2015; Mayorga et al., 2018). Reasons for the insulin response during HS are not fully understood but may be related to the fact that leukocytes are insulin responsive (Calder et al., 2007; Maratou et al., 2007) and LPS appears to have a role in stimulating insulin secretion (Baumgard et al., 2016). Additionally, HS slightly increased circulating NEFA, which disagrees with our previous HS reports (Rhoads et al., 2009; Shwartz et al., 2009; Wheelock et al., 2010) indicating a blunted basal and stimulated NEFA concentration during HS. Reasons for inconsistencies in circulating NEFA are likely due to the current study not using the pair-feeding design as in other experiments. The increase in NEFA described herein $(50 \%)$ is marginal compared with the large increases occurring in TN negative energy balance such as those described in the transition period (Grummer, 1993, 1995) or during feed restriction (Grummer et al., 1994; Carlson et al., 2006). Furthermore, HS increased circulating BHB (38\%), which agrees with other HS studies in cattle (Ronchi et al., 1999; Abeni et al., 2007). Reasons for increased circulating BHB during HS remain unclear because it could be due to increased pool entry (from the gastrointestinal tract or the liver) or decreased removal from the plasma pool. However, similar to NEFA, the increase in BHB is likely biologically inconsequential, especially considering the magnitude of change in BHB concentration ( $>4$-fold) that normally accompanies the transition period (Bobe et al., 2004; McArt et al., 2015). In agreement with HS studies conducted in environmental chambers (Rhoads et al., 2009; Wheelock et al., 2010; Cowley et al., 2015; Gao et al., 2017), HS caused increased BUN levels (18\%), which is likely due to increased AA utilization for gluconeogenesis and production of acute phase proteins (Baumgard and Rhoads, 2013). Because BUN transfers into milk on a concentration gradient (Roseler et al., 1993), it is not surprising that the temporal patterns of both BUN and MUN (described above) reflect each other.

As mentioned earlier, impaired intestinal barrier integrity is common during acute HS (Lambert et al., 2002; Pearce et al., 2013). Increased intestinal permeability leads to LPS translocation into portal and systemic circulation, which upon recognition by immune cells triggers an inflammatory response characterized by the production of acute phase proteins (Ceciliani et al., 2012). This APPR has an imperative role in pathogen opsonization, removal of toxic substances, and regulation of the innate immune system (Ceciliani et al., 2012). In the present study, HS increased circulating LBP and SAA (2- and 4-fold, respectively) relative to $\mathrm{P} 1$, which likely indicates an increased inflammatory response during HS; this agrees with our recent report in pigs (Mayorga et al., 2019). Interestingly, circulating SAA tended to decrease on d 5 in SCFP-fed cows during HS relative to $\mathrm{CON}$ cows. This is consistent with a previous study in which SCFP supplementation reduced APPR during the periparturient period (Knoblock et al., 2019). Reasons for reduced circulating SAA are not well defined but could be related to the immunomodulatory effect of SCFP. Despite the apparent decrease in peak SAA, circulating white blood cells and neutrophils were increased (9 and $26 \%$, respectively) in SCFP-fed cows compared with CON cows. Accurately interpreting these aforementioned discordant patterns 
is difficult, but results certainly suggest that SCFP has immunomodulatory effects during HS. Further investigating the effect of SCFP on immune system metrics during HS is of interest.

Heat stress increased cortisol concentrations in $\mathrm{CON}$ cows, but it remained unchanged during HS in SCFP-fed cows. Elevated cortisol is a classic endocrine response to stress (Binsiya et al., 2017; Sejian et al., 2018), and it corroborates previous HS studies in dairy cows (Titto et al., 2017; Hall et al., 2018) and calves (López et al., 2018) but is in contrast to HS heifers (Ronchi et al., 2001). Reasons for the inconsistencies in cortisol responses to HS are not clear, but identifying them may shed light on why there are inconsistencies in how HS affects some aspects of carbohydrate and lipid metabolism (Baumgard and Rhoads, 2013). Interestingly, SCFP-fed cows did not have an increase in circulating cortisol during HS, and this is consistent with previous studies where SCFP supplementation reduced circulating cortisol levels in transition dairy cows (Zaworski et al., 2014), heat-stressed broiler chickens (Nelson et al., 2018), and turkeys (Bartz et al., 2018). Reasons for reduced circulating cortisol following SCFP supplementation are not fully understood. Increased glucocorticoids are thought to negatively affect neutrophil function (Burton et al., 1995, 2005) and the immune response in general; thus, the blunted cortisol response reported herein could have a large effect on a variety of on-farm situations characterized by immune dysfunction (e.g., the transition period; Trevisi et al., 2012). Further research is needed to explain the mechanism (and consequences of) by which SCFP supplementation modifies the stress axis.

\section{CONCLUSIONS}

Using the EHB increased all body temperature variables, caused inflammation, and reduced production variables (i.e., DMI and milk yield). Herein, we demonstrated that feeding SCFP could be beneficial at reducing circulating cortisol and the APPR and increasing key leukocytes during stressful conditions. Overall, feeding SCFP altered the metabolic and immune profile in heat-stressed dairy cows, and these changes are presumably reflective of a reduced stressed state.

\section{ACKNOWLEDGMENTS}

Results described herein were funded in part by Diamond V (Cedar Rapids, IA) and the Norman Jacobson Endowed Professorship. I. Yoon is an employee of Diamond V, but all other authors have not stated any conflicts of interest.

\section{REFERENCES}

Abeni, F., L. Calamari, and L. Stefanini. 2007. Metabolic conditions of lactating Friesian cows during the hot season in the Po valley. 1. Blood indicators of heat stress. Int. J. Biometeorol. 52:87-96. https://doi.org/10.1007/s00484-007-0098-3.

Acharya, S., J. P. Pretz, I. Yoon, M. F. Scott, and D. P. Casper. 2017. Effect of Saccharomyces cerevisiae fermentation products on the lactational performance of mid-lactation dairy cows. Transl. Anim. Sci. 1:221-228. https://doi.org/10.2527/tas2017.0028.

Achmadi, J., T. Yanagisawa, H. Sano, and Y. Terashima. 1993. Pancreatic insulin secretory response and insulin action in heat exposed sheep given a concentrate or roughage diet. Domest. Anim. Endocrinol. 10:279-287. https://doi.org/10.1016/0739-7240(93)90032-7.

Al-Qaisi, M. E. A. Horst, S. K. Kvidera, E. J. Mayorga, L. L. Timms, and L. H. Baumgard. 2019. Technical note: Developing a heat stress model in dairy cows using an electric heat blanket. J. Dairy Sci. 102:684-689. https://doi.org/10.3168/jds.2018-15128.

Al-Qaisi, M., E. J. Mayorga, E. A. Horst, S. K. Kvidera, C. S. McCarthy, M. A. Abeyta, B. M. Goetz, H. A. Ramirez Ramirez, L. L. Timms, and L. H. Baumgard. 2020. Validating a heat stress model: The effects of an electric heat blanket and nutritional plane on lactating dairy cows. J. Dairy Sci. 103:5550-5560. https://doi .org/10.3168/jds.2019-17543.

AOAC International. 1995. AOAC official method 972.16. Fat, lactose, protein, and solids in milk. Mid infrared spectroscopic method. Pages 23-26 in Official Methods of Analysis. 16th ed. Vol. 2. AOAC International, Arlington, VA.

Armstrong, D. V. 1994. Heat stress interaction with shade and cooling. J. Dairy Sci. 77:2044-2050. https://doi.org/10.3168/jds.S0022 -0302(94)77149-6.

Bandaranayaka, D., and C. Holmes. 1976. Changes in the composition of milk and rumen contents in cows exposed to a high ambient temperature with controlled feeding. Trop. Anim. Health Prod. 8:38-46. https://doi.org/10.1007/BF02383364.

Bartz, B. M., D. R. McIntyre, and J. L. Grimes. 2018. Effects of management related practices on turkey hen performance supplemented with either original XPC ${ }^{\mathrm{TM}}$ or AviCare ${ }^{\mathrm{TM}}$. Front. Vet. Sci. 5:185. https://doi.org/10.3389/fvets.2018.00185.

Bauman, D. E., J. W. Perfield 2nd, K. J. Harvatine, and L. H. Baumgard. 2008. Regulation of fat synthesis by conjugated linoleic acid: Lactation and the ruminant model. J. Nutr. 138:403-409. https:// doi.org/10.1093/jn/138.2.403

Baumgard, L. H., G. J. Hausman, and M. V. Sanz Fernandez. 2016. Insulin: Pancreatic secretion and adipocyte regulation. Domest. Anim. Endocrinol. 54:76-84. https://doi.org/10.1016/j.domaniend .2015.07.001.

Baumgard, L. H., and R. P. Rhoads Jr.. 2013. Effects of heat stress on postabsorptive metabolism and energetics. Annu. Rev. Anim. Biosci. 1:311-337. https://doi.org/10.1146/annurev-animal-031412 -103644 .

Baumgard, L. H., J. B. Wheelock, S. R. Sanders, C. E. Moore, H. B. Green, M. R. Waldron, and R. P. Rhoads. 2011. Postabsorptive carbohydrate adaptations to heat stress and monensin supplementation in lactating Holstein cows. J. Dairy Sci. 94:5620-5633. https://doi.org/10.3168/jds.2011-4462.

Bernabucci, U., N. Lacetera, L. H. Baumgard, R. P. Rhoads, B. Ronchi, and A. Nardone. 2010. Metabolic and hormonal acclimation to heat stress in domesticated ruminants. Animal 4:1167-1183. https: //doi.org/10.1017/S175173111000090X.

Binsiya, T. K., V. Sejian, M. Bagath, G. Krishnan, I. Hyder, A. Manimaran, A. M. Lees, J. B. Gaughan, and R. Bhatta. 2017. Significance of hypothalamic-pituitary-adrenal axis to adapt to climate change in livestock. Int. Res. J. Agric. Food Sci. 2:1-20.

Bluel, R. J. V. 2006. The effects of supplemental anionic salts and yeast culture on the production of dairy cattle during the periparturient period. MS Thesis. Univ. Missouri, Columbia.

Bobe, G., J. W. Young, and D. C. Beitz. 2004. Invited review: Pathology, etiology, prevention, and treatment of fatty liver in dairy 
cows. J. Dairy Sci. 87:3105-3124. https://doi.org/10.3168/jds S0022-0302(04)73446-3.

Bouraoui, R., M. Lahmar, A. Majdoub, M. Djemali, and R. Belyea. 2002. The relationship of temperature-humidity index with milk production of dairy cows in a Mediterranean climate. Anim. Res. 51:479-491. https://doi.org/10.1051/animres:2002036.

Broadway, P. R., J. A. Carroll, and N. C. Sanchez. 2015. Live yeast and yeast cell wall supplements enhance immune function and performance in food-producing livestock: A review. Microorganisms 3:417-427. https://doi.org/10.3390/microorganisms3030417.

Bruno, R. G. S., H. M. Rutigliano, R. L. Cerri, P. H. Robinson, and J. E. P. Santos. 2009. Effect of feeding Saccharomyces cerevisiae on performance of dairy cows during summer heat stress. Anim. Feed Sci. Technol. 150:175-186. https://doi.org/10.1016/j.anifeedsci .2008.09.001.

Burton, J. L., M. E. Kehrli Jr., S. Kapil, and R. L. Horst. 1995. Regulation of L-selectin and CD18 on bovine neutrophils by glucocorticoids: Effects of cortisol and dexamethasone. J. Leukoc. Biol. 57:317-325. https://doi.org/10.1002/jlb.57.2.317.

Burton, J. L., S. A. Madsen, L. C. Chang, P. S. D. Weber, K. R. Buckham, R. van Dorp, M. C. Hickey, and E. Bernadette. 2005. Gene expression signatures in neutrophils exposed to glucocorticoids: A new paradigm to help explain "neutrophil dysfunction" in parturient dairy cows. Vet. Immunol. Immunopathol. 105:197-219. https: //doi.org/10.1016/j.vetimm.2005.02.012.

Calder, P. C., G. Dimitriadis, and P. Newsholme. 2007. Glucose metabolism in lymphoid and inflammatory cells and tissues. Curr. Opin. Clin. Nutr. Metab. Care 10:531-540. https://doi.org/10 .1097/MCO.0b013e3281e72ad4.

Carlson, D. B., N. B. Litherland, H. M. Dann, J. C. Woodworth, and J. K. Drackley. 2006. Metabolic effects of abomasal L-carnitine infusion and feed restriction in lactating Holstein cows. J. Dairy Sci. 89:4819-4834. https://doi.org/10.3168/jds.S0022-0302(06)72531 -0 .

Ceciliani, F., J. J. Ceron, P. D. Eckersall, and H. Sauerwein. 2012. Acute phase proteins in ruminants. J. Proteomics 75:4207-4231. https://doi.org/10.1016/j.jprot.2012.04.004.

Chouinard, P. Y., L. Corneau, A. Saebo, and D. E. Bauman. 1999. Milk yield and composition during abomasal infusion of conjugated linoleic acid. J. Dairy Sci. 82:2737-2745. https://doi.org/10 .3168/jds.S0022-0302(99)75530-X.

Collin, A., J. van Milgen, S. Dubois, and J. Noblet. 2001. Effect of high temperature on feeding behavior and heat production in group-housed young pigs. Br. J. Nutr. 86:63-70.

Cowley, F. C., D. G. Barber, A. V. Houlihan, and D. P. Poppi. 2015. Immediate and residual effects of heat stress and restricted intake on milk protein and casein composition and energy metabolism. J. Dairy Sci. 98:2356-2368. https://doi.org/10.3168/jds.2014-8442.

Cronje, P. 2005. Heat stress in livestock-The role of the gut in its aetiology and a potential role for betaine in its alleviation. Pages 107-122 in Recent Advances in Animal Nutrition in Australia. Vol. 15. University of New England, Armidale, NSW, Australia.

Dann, H. M., J. K. Drackley, G. C. McCoy, M. F. Hutjens, and J. E. Garrett. 2000. Effects of yeast culture (Saccharomyces cerevisiae) on prepartum intake and postpartum intake and milk production of Jersey cows. J. Dairy Sci. 83:123-127. https://doi.org/10.3168/ jds.S0022-0302(00)74863-6.

Erasmus, L. J., P. H. Robinson, A. Ahmadi, R. Hinders, and J. E. Garrett. 2005. Influence of prepartum and postpartum supplementation of a yeast culture and monensin, or both, on ruminal fermentation and performance of multiparous dairy cows. Anim. Feed Sci. Technol. 122:219-239. https://doi.org/10.1016/j.anifeedsci 2005.03.004

Gao, S. T., J. Guo, S. Y. Quan, X. M. Nan, M. V. Sanz Fernandez, L. H. Baumgard, and D. Bu. 2017. The effects of heat stress on protein metabolism in lactating Holstein cows. J. Dairy Sci. 100:5040-5049. https://doi.org/10.3168/jds.2016-11913.

Grummer, R. R. 1993. Etiology of lipid-related metabolic disorders in periparturient dairy cows. J. Dairy Sci. 76:3882-3896. https://doi .org/10.3168/jds.S0022-0302(93)77729-2.
Grummer, R. R. 1995. Impact of changes in organic nutrient metabolism on feeding the transition dairy cow. J. Anim. Sci. 73:28202833. https://doi.org/10.2527/1995.7392820x.

Grummer, R. R., J. C. Winkler, S. J. Bertics, and V. A. Studer. 1994. Effect of propylene glycol dosage during feed restriction on metabolites in blood of prepartum Holstein heifers. J. Dairy Sci. 77:36183623. https://doi.org/10.3168/jds.S0022-0302(94)77306-9.

Hall, D. M., G. R. Buettner, L. W. Oberley, L. Xu, R. D. Matthes, and C. V. Gisolfi. 2001. Mechanisms of circulatory and intestinal barrier dysfunction during whole body hyperthermia. Am. J. Physiol. Heart Circ. Physiol. 280:H509-H521. https://doi.org/10 .1152/ajpheart.2001.280.2.H509.

Hall, L. W., F. Villar, L. D. Chapman, D. J. McLean, N. M. Long Y. Xiao, J. L. Collier, and R. J. Collier. 2018. An evaluation of an immunomodulatory feed ingredient in heat-stressed lactating Holstein cows: Effects on hormonal, physiological, and production responses. J. Dairy Sci. 101:7095-7105. https://doi.org/10.3168/ jds.2017-14210.

Hara, A., and N. S. Radin. 1978. Lipid extraction of tissues with a low-toxicity solvent. Anal. Biochem. 90:420-426. https://doi.org/ 10.1016/0003-2697(78)90046-5.

Hays, W. P. 1926. The effect of environmental temperature on the percentage of fat in cow's milk. J. Dairy Sci. 9:219-235. https:// doi.org/10.3168/jds.S0022-0302(26)93890-3.

Hinz, K., L. B. Larsen, O. Wellnitz, R. M. Bruckmaier, and A. L. Kelly. 2012. Proteolytic and proteomic changes in milk at quarter level following infusion with Escherichia coli lipopolysaccharide. J. Dairy Sci. 95:1655-1666. https://doi.org/10.3168/jds.2011-4813.

Huber, J. T. 1996. Amelioration of heat stress in dairy cattle. Pages 211-243 in Progress in Dairy Science. C. J. C. Philips, ed. CAB International, Wallingford, UK.

Ibeagha-Awemu, E. M., J. W. Lee, A. E. Ibeagha, D. D. Bannerman, M. J. Paape, and X. Zhao. 2008. Bacterial lipopolysaccharide induced increased expression of toll-like receptor (TLR) 4 and downstream TLR signaling molecules in bovine mammary epithelial cells. Vet. Res. 39:11. https://doi.org/10.1051/vetres:2007047.

Itoh, F., Y. Obara, M. T. Rose, H. Fuse, and H. Hashimoto. 1998. Insulin and glucagon secretion in lactating cows during heat exposure. J. Anim. Sci. 76:2182-2189. https://doi.org/10.2527/1998 $.7682182 x$

Jiang, Y., I. M. Ogunade, D. H. Kim, X. Li, A. A. Pech-Cervantes, K. G. Arriola, A. S. Oliveira, J. P. Driver, L. F. Ferraretto, C. R Staples, D. Vyas, and A. T. Adesogan. 2018. Effect of adding clay with or without a Saccharomyces cerevisiae fermentation product on the health and performance of lactating dairy cows challenged with dietary aflatoxin $B_{1}$. J. Dairy Sci. 101:3008-3020. https://doi .org/10.3168/jds.2017-13678.

Johnson, R. W. 2012. Fueling the immune response: What's the cost? Pages 211-223 in Feed Efficiency in Swine. J. Patience, ed. Wageningen Academic Publishers, Wageningen, the Netherlands.

Kadzere, C. T., M. R. Murphy, N. Silanikove, and E. Maltz. 2002. Heat stress in lactating dairy cows: A review. Livest. Prod. Sci. 77:59-91. https://doi.org/10.1016/S0301-6226(01)00330-X.

Key, N., and S. Sneeringer. 2014. Potential effects of climate change on the productivity of U.S dairies. Am. J. Agric. Econ. 96:1136-1156. https://doi.org/10.1093/ajae/aau002.

Knoblock, C. E., W. Shi, I. Yoon, and M. Oba. 2019. Effects of supplementing a Saccharomyces cerevisiae fermentation product during the periparturient period on the immune response of dairy cows fed fresh diets differing in starch content. J. Dairy Sci. 102:61996209. https://doi.org/10.3168/jds.2018-16224.

Koch, F., U. Thom, E. Albrecht, R. Weikard, W. Nolte, B. Kuhla, and C. Kuehn. 2019. Heat stress directly impairs gut integrity and recruits distinct immune cell populations into the bovine intestine. Proc. Natl. Acad. Sci. USA 116:10333-10338. https://doi.org/10 .1073/pnas.1820130116.

Kvidera, S. K., E. A. Horst, M. Abuajamieh, E. J. Mayorga, M. V. Sanz Fernandez, and L. H. Baumgard. 2017. Glucose requirements of an activated immune system in lactating Holstein cows. J. Dairy Sci. 100:2360-2374. https://doi.org/10.3168/jds.2016-12001. 
Lambert, G. P. 2009. Stress-induced gastrointestinal barrier dysfunction and its inflammatory effects. J. Anim. Sci. 87(Suppl. 14):E101-E108. https://doi.org/10.2527/jas.2008-1339.

Lambert, G. P., C. V. Gisolfi, D. J. Berg, P. L. Moseley, L. W. Oberley, and K. C. Kregel. 2002. Selected contribution: Hyperthermia-induced intestinal permeability and the role of oxidative and nitrosative stress. J. Appl. Physiol. 92:1750-1761., discussion 1749. https: //doi.org/10.1152/japplphysiol.00787.2001.

Li, S., I. Yoon, M. Scott, E. Khafipour, and J. C. Plaizier. 2016. Impact of Saccharomyces cerevisiae fermentation product and subacute ruminal acidosis on production, inflammation, and fermentation in the rumen and hindgut of dairy cows. Anim. Feed Sci. Technol. 211:50-60. https://doi.org/10.1016/j.anifeedsci.2015.10.010.

López, E., M. Mellado, A. M. Martinez, F. G. Veliz, J. E. Garcia, A. de Santiago, and E. Carrillo. 2018. Stress-related hormonal alterations, growth and pelleted starter intake in pre-weaning Holstein calves in response to thermal stress. Int. J. Biometeorol. 62:493500. https://doi.org/10.1007/s00484-017-1458-2.

Maratou, E., G. Dimitriadis, A. Kollias, E. Boutati, V. Lambadiari, P. Mitrou, and S. A. Raptis. 2007. Glucose transporter expression on the plasma membrane of resting and activated white blood cells. Eur. J. Clin. Invest. 37:282-290. https://doi.org/10.1111/j.1365 $-2362.2007 .01786 . x$.

Mayorga, E. J., S. K. Kvidera, E. A. Horst, M. Al-Qaisi, M. J. Dickson, J. T. Seibert, S. Lei, A. F. Keating, J. W. Ross, R. P. Rhoads, Z. J. Rambo, M. E. Wilson, and L. H. Baumgard. 2018. Effects of zinc amino acid complex on biomarkers of gut integrity and metabolism during and following heat stress or feed restriction in pigs. J. Anim. Sci. 96:4173-4185. https://doi.org/10.1093/jas/ sky293.

Mayorga, E. J., S. K. Kvidera, J. T. Seibert, E. A. Horst, M. Abuajamieh, M. Al-Qaisi, S. Lei, J. W. Ross, C. D. Johnson, B. Kremer, L. Ochoa, R. P. Rhoads, and L. H. Baumgard. 2019. Effects of dietary chromium propionate on growth performance, metabolism, and immune biomarkers in heat-stressed finishing pigs. J. Anim. Sci. 97:1185-1197. https://doi.org/10.1093/jas/sky484.

McArt, J. A., D. V. Nydam, and M. W. Overton. 2015. Hyperketonemia in early lactation dairy cattle: A deterministic estimate of component and total cost per case. J. Dairy Sci. 98:2043-2054. https://doi.org/10.3168/jds.2014-8740.

Moody, E. G., P. J. Van Soest, R. E. McDowell, and G. L. Ford. 1971. Effect of high temperature and dietary fat on milk fatty acids. J. Dairy Sci. 54:1457-1460. https://doi.org/10.3168/jds.S0022 -0302(71)86046-0.

National Research Council. 2001. Nutrient Requirements of Dairy Cattle. 7th rev. ed. Nat. Acad. Press, Washington, DC.

Nelson, J. R., D. R. McIntyre, H. O. Pavlidis, and G. S. Archer. 2018. Reducing stress susceptibility of broiler chickens by supplementing a yeast fermentation product in the feed or drinking water. Animals (Basel) 8:173. https://doi.org/10.3390/ani8100173.

Ning, L. T., G. Z. Dong, C. Ao, D. G. Zhang, K. Erdene, F. Q. Zhang, J. Wen, and T. L. Zhang. 2018. Effects of continuous low dose infusion of lipopolysaccharide on inflammatory responses, milk production and milk quality in dairy cows. J. Anim. Physiol. Anim. Nutr. (Berl.) 102:e262-e269. https://doi.org/10.1111/jpn.12737.

O'Brien, M. D., R. P. Rhoads, S. R. Sanders, G. C. Duff, and L. H. Baumgard. 2010. Metabolic adaptations to heat stress in growing cattle. Domest. Anim. Endocrinol. 38:86-94. https://doi.org/10 .1016/j.domaniend.2009.08.005.

Pearce, S. C., V. Mani, R. L. Boddicker, J. S. Johnson, T. E. Weber, J. W. Ross, R. P. Rhoads, L. H. Baumgard, and N. K. Gabler. 2013. Heat stress reduces intestinal barrier integrity and favors intestinal glucose transport in growing pigs. PLoS One 8:e70215. https://doi .org/10.1371/journal.pone.0070215.

Poppy, G. D., A. R. Rabiee, I. J. Lean, W. K. Sanchez, K. L. Dorton, and P. S. Morley. 2012. A meta-analysis of the effects of feeding yeast culture produced by anaerobic fermentation of Saccharomyces cerevisiae on milk production of lactating dairy cows. J. Dairy Sci. 95:6027-6041. https://doi.org/10.3168/jds.2012-5577.

Ramsing, E. M., J. A. Davidson, P. D. French, I. Yoon, M. Keller, and H. Peters-Fleckenstein. 2009. Effect of yeast culture on peripartum intake and milk production of primiparous and multiparous Holstein cows. Prof. Anim. Sci. 25:487-495. https://doi.org/10.15232/ S1080-7446(15)30739-7.

Regan, W. M., and G. A. Richardson. 1938. Reactions of the dairy cow to changes in environmental temperature. J. Dairy Sci. 21:73-79. https://doi.org/10.3168/jds.S0022-0302(38)95617-6.

Rhoads, M. L., R. P. Rhoads, M. J. VanBaale, R. J. Collier, S. R. Sanders, W. J. Weber, B. A. Crooker, and L. H. Baumgard. 2009. Effects of heat stress and plane of nutrition on lactating Holstein cows: I. Production, metabolism, and aspects of circulating somatotropin. J. Dairy Sci. 92:1986-1997. https://doi.org/10.3168/ jds.2008-1641.

Ronchi, B., U. Bernabucci, N. Lacetera, A. Verini Supplizi, and A. Nardone. 1999. Distinct and common effects of heat stress and restricted feeding on metabolic status of Holstein heifers. Zootec. Nutr. Anim. 25:11-20.

Ronchi, B., G. Stradaioli, A. Verini Supplizi, U. Bernabucci, N. Lacetera, P. A. Accorsi, A. Nardone, and E. Seren. 2001. Influence of heat stress or feed restriction on plasma progesterone, oestradiol-173, LH, FSH, prolactin and cortisol in Holstein heifers. Livest. Prod. Sci. 68:231-241. https://doi.org/10.1016/S0301 $-6226(00) 00232-3$.

Roseler, D. K., J. D. Ferguson, C. J. Sniffen, and J. Herrema. 1993. Dietary protein degradability effects on plasma and milk urea nitrogen and milk nonprotein nitrogen in Holstein cows. J. Dairy Sci. 76:525-534. https://doi.org/10.3168/jds.S0022-0302(93)77372-5.

Sanz Fernandez, M. V., S. C. Pearce, N. K. Gabler, J. F. Patience, M. E. Wilson, M. T. Socha, J. L. Torrison, R. P. Rhoads, and L. H. Baumgard. 2014. Effects of supplemental zinc amino acid complex on gut integrity in heat-stressed growing pigs. Animal 8:43-50. https://doi.org/10.1017/S1751731113001961.

Sanz Fernandez, M. V., S. K. Stoakes, M. Abuajamieh, J. T. Seibert, J. S. Johnson, E. A. Horst, R. P. Rhoads, and L. H. Baumgard. 2015. Heat stress increases insulin sensitivity in pigs. Physiol. Rep. 3:e12478. https://doi.org/10.14814/phy2.12478.

Schingoethe, D. J., K. N. Linke, K. F. Kalscheur, A. R. Hippen, D. R. Rennich, and I. Yoon. 2004. Feed efficiency of mid lactation dairy cows fed yeast culture during summer. J. Dairy Sci. 87:4178-4181. https://doi.org/10.3168/jds.S0022-0302(04)73561-4.

Sejian, V., R. Bhatta, J. B. Gaughan, F. R. Dunshea, and N. Lacetera. 2018. Review: Adaptation of animals to heat stress. Animal 12(Suppl. 2):s431-s444. https://doi.org/10.1017/S1751731118001945.

Shi, W., C. E. Knoblock, K. V. Murphy, T. C. Bruinje, I. Yoon, D. J. Ambrose, and M. Oba. 2019. Effects of supplementing a Saccharomyces cerevisiae fermentation product during the periparturient period on performance of dairy cows fed fresh diets differing in starch content. J. Dairy Sci. 102:3082-3096. https://doi.org/10 .3168/jds.2018-15307.

Shurson, G. C. 2018. Yeast and yeast derivatives in feed additives and ingredients: Sources, characteristics, animal responses, and quantification methods. Anim. Feed Sci. Technol. 235:60-76. https://doi .org/10.1016/j.anifeedsci.2017.11.010.

Shwartz, G., M. L. Rhoads, M. J. VanBaale, R. P. Rhoads, and L. H. Baumgard. 2009. Effects of a supplemental yeast culture on heatstressed lactating Holstein cows. J. Dairy Sci. 92:935-942. https:/ /doi.org/10.3168/jds.2008-1496.

ten Napel, J., Y. de Haas, G. de Jong, T. J. G. M. Lam, W. Ouweltjes, and J. J. Windig. 2009. Characterization of distributions of somatic cell count. J. Dairy Sci. 92:1253-1264. https://doi.org/10 $.3168 /$ jds.2007-0824.

Titto, C. G., J. A. Negrão, T. S. Canaes, R. M. Titto, T. M. C. Lemedos Santos, F. L. Henrique, R. F. Calviello, A. M. F. Pereira, and E. A. L. Titto. 2017. Heat stress and ACTH administration on cortisol and insulin-like growth factor I levels in lactating Holstein cows. J. Appl. Anim. Res. 45:1-7. https://doi.org/10.1080/ 09712119.2015.1091326.

Trevisi, E., M. Amadori, S. Cogrossi, E. Razzuoli, and G. Bertoni. 2012. Metabolic stress and inflammatory response in high yielding, periparturient dairy cows. Res. Vet. Sci. 93:695-704. https://doi .org/10.1016/j.rvsc.2011.11.008. 
Vailati-Riboni, M., D. Coleman, V. Lopreiato, A. Alharthi, R. Bucktrout, E. Trevisi, I. Yoon, and J. J. Loor. 2019. Feeding NutriTek improves udder health and systemic response during a Streptococcus uberis mastitis challenge in mid-lactating dairy cows. J. Dairy Sci. 102(Suppl. 1):349. (Abstr.)

Volman, J. J., J. D. Ramakers, and L. Plat. 2008. Dietary modulation of immune function by $\beta$-glucans. Physiol. Behav. 94:276-284. https://doi.org/10.1016/j.physbeh.2007.11.045.

Wheelock, J. B., R. P. Rhoads, M. J. VanBaale, S. R. Sanders, and L. H. Baumgard. 2010. Effects of heat stress on energetic metabolism in lactating Holstein cows. J. Dairy Sci. 93:644-655. https://doi .org/10.3168/jds.2009-2295.

Yuan, K., L. G. D. Mendonca, L. E. Hulbert, L. K. Mamedova, M. B. Muckey, Y. Shen, C. C. Elrod, and B. J. Bradford. 2015. Yeast product supplementation modulated humoral and mucosal immunity and uterine inflammatory signals in transition dairy cows. J. Dairy Sci. 98:3236-3246. https://doi.org/10.3168/jds.2014-8469.

Zaworski, E. M., C. M. Shriver-Munsch, N. A. Fadden, W. K. Sanchez, I. Yoon, and G. Bobe. 2014. Effects of feeding various dosages of Saccharomyces cerevisiae fermentation product in transition dairy cows. J. Dairy Sci. 97:3081-3098. https://doi.org/10.3168/jds.2013 -7692 .

Zhu, W., B. X. Zhang, K. Y. Yao, I. Yoon, Y. H. Chung, J. K. Wang, and J. X. Liu. 2016. Effects of supplemental levels of Saccharomyces cerevisiae fermentation product on lactation performance in dairy cows under heat stress. Asian-Australas. J. Anim. Sci. 29:801-806. https://doi.org/10.5713/ajas.15.0440. 